The quoted covenant avoids this result by requiring, in effect, that resort to financing by sale and leaseback be had only when the company might incur more funded indebtedness as an alternative. But if the business world shows its intention to treat the sale and leaseback agreement as a loan for one purpose, it ought not to be shocked if the Bureau of Internal Revenue formulated the policy of so treating the transaction for tax purposes. Similarly, since management has been willing to permit the treatment of the leaseback as a loan for one purpose, an inference may be drawn as to acceptable methods of accounting disclosure. The special security clauses in bond indentures stand as condemnations of the present balance sheet treatment of sale and leaseback transactions.

Full disclosure of information about leaseback arrangements in the annual reports to stockholders will give them the opportunity of making informed judgments for themselves. However, since there is no regulating agency with the power to prescribe uniform accounting practices for industrial and merchandising corporations, it is likely that a considerable length of time will pass before the needs of investors and creditors will be able to effect adequate balance sheet presentation for leaseback arrangements in the annual reports to stockholders through the medium of concerted pressure upon corporations by the Securities and Exchange Commission, investors' services, the accounting profession and the bar.

\title{
LEGAL BARRIERS CONFRONTING THIRD PARTIES: THE PROGRESSIVE PARTY IN IILINOIS
}

Recent events have produced considerable controversy as to whether or not statutory provisions in the various states present a serious obstacle to the success of minority political parties. ${ }^{x}$ To the traditional view that existing statutes have a controlling adverse effect ${ }^{2}$ has been opposed the view of a small number of political scientists who contend that the purported lack of success of minority parties is due, in the main, to factors more deeply imbedded in our political structure. ${ }^{3}$ This latter view seems to have received at least some confirmation from the elections of November 1948 in which the newest of the "third parties," the Progressive Party, was able to obtain a place on the ballot in forty-five states, but received surprisingly little support.

Illinois was the scene of the most heated fight with respect to the right of the Progressive Party to appear on the ballot. Candidates for offices within Cook County were able to secure their places only after protracted litigation in the state courts, and candidates for national and state-wide offices were barred al-

I A tabulation of the statutory provisions governing minor political parties is provided in Legal Obstacles to Minority Party Success, 57 Yale L.J. I276, I 292-97 (I948).

2 Brooks, Political Parties and Electoral Problems I22, 265 (3d ed., I933); Odegard and Helms, American Politics 782 (1938).

${ }^{3}$ Sait, American Parties and Elections 304 (3d ed., I942). 
together after a decision by the United States Supreme Court. 4 An examination of the legal procedures necessitated by Tllinois law which lead to these results should illuminate the entire controversy. Several unusual questions of substantive and procedural law were involved, and many provisions of the Illinois Election Code $^{5}$ were construed for the first time. The United States Supreme Court again considered the problem of the extent to which it will, under the Fourteenth Amendment, protect civil liberties by interfering with state laws dealing with political matters. Furthermore, the litigation was at every stage so colored by the political climate in Illinois as to discredit any assumption that the effect of minority party legislation can be determined merely by an examination of the relevant statutory provisions. And finally, the litigation raises once again the questions of the part which minority parties play in the American political scheme and of the policy which 'the courts and legislature should properly adopt toward them.

It is proposed to examine first the legal proceedings centering around the efforts of the Progressive Party to become an "established political party" within Cook County, and then to consider the Party's efforts to place on the ballot the names of its candidates for national and state-wide offices.

\section{I}

Article Io of the Illinois Election Code makes a distinction between a "new political party" and an "established political party." An established party is required to make its nominations through the mechanism of the Primary Act, ${ }^{6}$ while a new party must make its nominations by a petition procedure described in Article ro. Section 2 of Article ro provides that in the event the leading candidate of such new party, for any office within any subdivision of the state, shall receive more than five per cent of the total vote cast at the next ensuing election following the making of such nominations by petition, then that party shall become an established political party within that subdivision of the state. Having become established, the party "shall thereafter nominate its candidates for public offices... under the provisions of the laws regulating the nomination of candidates of established political parties at primary elections ... as now or hereafter in force."?

Section 2 of Article Io also states the requirements which the nominating petitions for new party candidates must fulfill where the candidacy is for a county office:

4 MacDougall v. Green, 335 U.S. 28I (r948).

5 Ill. Ann. Stat. (Smith-Hurd, r948) c. 46. Hereinafter referred to as Election Code.

${ }^{6}$ Election Code Art. 7.

7 Election Code Art. Io, $\S 2$. Any established party will automatically lose its 'established' status if it (i.e., its leading candidate) fails to get five per cent of the vote cast at a general election for state and county officers within the state, county, or congressional district. Election Code Art. 7, \$2. 
If such new party shall pe rorined for any district or political subdivision less than the entire State, such petition shall be signed by qualified voters equalling in number not less than five (5) per cent nor more than eight (8) per cent of the number of voters who voted at the next preceding general election in such district or political subdivision in which such district or political subdivision voted as a unit for the election of officers to serve its respective territorial area. ...8

On November 4, I947, an election was held in Cook County for the purpose of electing twenty-one judges to the Superior Court of Cook County. Prior to this election the organizers of the Progressive Party had circulated nominating petitions within the county and these were accepted by the County Clerk of Cook County. No objections to the petitions were filed, and as a result twentyone Progressive Party candidates appeared on the November 4 ballot under the appropriate party label.9

The leading Progressive Party candidate received forty-four per cent of the vote cast in the county. His total included over five per cent of the vote cast in each of the twelve congressional districts lying wholly within Cook County, in the City of Chicago, and in the Chicago Sanitary District. The Progressives believed that this constituted them an established political party within Cook County and each of the subdivisions thereof, and thereby entitled them to participate in the primary election scheduled for April I3, I948, for the purpose of nominating candidates to be elected in the November elections.

The Party accordingly prepared to take certain steps consonant with its presumed status. Pursuant to provisions of Section 2 of Article ro, the twenty-one judicial candidates met immediately following the election and selected persons to serve as Ward and Township Committeemen within Cook County, such persons to be known as The Provisional Cook County Central Committee, having the statutory duty of exercising "the powers conferred by law upon any party committeeman or committeemen to manage and control the affairs of such new political party until the next ensuing primary election at which said new political party shall be entitled to nominate and elect any party committeeman or committeemen ... under any parts of this Act relating to the organization of political parties."

Section ro of Article 7 provides that each candidate whose name appears on the primary ballot shall have had fled on his behalf a petition containing the signatures of a certain percentage of the "qualified primary electors" of his party within the particular district or subdivision in which he is a candidate. ${ }^{1 x}$ The

8 The petition requirements for candidates for state-wide offices are cited in note 65 infra.

9 If the petitions are in apparent conformity with the statute, and if no objections thereto are filed, the petitions shall be deemed valid, and the receiving officer has a mandatory duty to certify the names for appearance on the ballot. Election Code Art. Io, $\$ 8$.

10 Election Code Art. ro, $\$ 2$.

Ix Thus, a candidate for congressional office must obtain signatures of one-half of one per cent of the qualified primary electors in the district. Candidates for county and city offices require the same percentages within their respective districts. Candidates for Ward Committeemen (who are actually elected and not merely nominated at the primary) require between ten and sixteen per cent. Election Code Art. $7, \S$ Io. 
number of primary electors is determined by the total vote cast for the candidate of such political party who received the highest number of votes in the state or subdivision thereof at the last general election..$^{\text {I2 }}$ Section 2 of Article 7 in defining a political party entitled to make use of the Act states: "A political party, which at the general election for State and County officers then next preceding a primary, cast more than 5 per cent of the vote cast in any county, is hereby declared to be a political party within the meaning of this Article, within the county. ..."'r3 Section 4 of Article 7 , however, states that the terms 'election' or 'general election' when used in Article 7 shall not include an election at which judges exclusively are elected, unless such definition be inconsistent with the context.

When it affirmatively appeared that certain public officials charged with various duties under the Election Code would, in reliance upon the above sections of Article 7, refuse to recognize the Progressive Party of Cook County as an established party entitled to a ballot in the April primary, ${ }^{\mathrm{r}} 4$ and would refuse to accept their petitions, the Progressive Party filed a complaint in the Circuit Court of Cook County asking for declaratory relief. The complaint, filed December 3, I947, named the County Clerk of Cook County and certain other public officers as defendants, ${ }^{15}$ and asked for a declaratory judgment under the Illinois Declaratory Judgments Act ${ }^{16}$ to the effect that the Progressive Party was an established political party within Cook County, and that the defendants were each under a duty to perform certain acts to the end that the party have a place in the primary election of April I3, I948.

The plaintiff maintained that the ambiguities of Article 7 and the apparent impossibility of meeting its signature requirements deprived it of substantial rights to which it was entitled by virtue of having qualified as an established political party under Article ro. The Party alleged that an actual controversy existed with regard to the interpretation of a statute, and that it would be un-

23 Election Code Art. 7, § ro.

13 Election Code Art. 7, § 2. Italics added.

${ }^{24}$ On November 22 the Progressive Party sent letters to each of several public officials charged with duties under the Election Code, requesting clarification of the signature requirements with regard to the primary election. An answer was received from the Chicago Board of Election Commissioners denying that the Progressives were an established political party and stating that there was no means by which they could appear on the primary ballot. No answers were received from the other defendants. Progressive Party v. Flynn, 400 III. IO2, 79 N.E. 2d 516 (I948), Plaintiff's Abstract of Record at I7-2I. Hereinafter referred to as Plaintiff's Abstract.

Is Specifically, the other defendants were: the City Clerk of Chicago, charged with certain duties with respect to the certificates of nomination for the Municipal Court of Chicago; the Secretary of State of Illinois, charged with the duty to receive and certify petitions for nomination of representatives in the United States Congress from the twelve congressional districts lying wholly within Cook County; and the Chicago Board of Election Commissioners, which has the duty of serving as an electoral board to pass upon objections to petitions for nomination of Ward Committeemen. The relevant sections of the Election Code are Art. 7, $\S \S$ I2-I7.

${ }^{16}$ IIl. Ann. Stat. (Smith-Hurd, I948) c. Iro, § I8r.I. 
able to obtain a writ of mandamus to compel defendants to act because the time for action had not yet arrived. If the plaintiff waited until the defendants had actually rejected the primary nominating petitions before taking action, the primary would have been held before any adjudication could be obtained. ${ }^{77}$

The defendants, other than the defendant Secretary of State, answered jointly, denying that the Progressives were an established political party. They also counterclaimed asking for a declaratory judgment declaring that the Progressive Party was not an established political party because a judicial election is not an election which may be used as the basis of establishing a new party, and declaring that the defendants were under a duty not to receive any nominating papers. ${ }^{x}$ The defendant Secretary of State moved to strike the complaint and dismiss the suit, alleging that the court was without jurisdiction because all questions involved were "political" questions and because the suit was, in substançe, one against the State in violation of the state's immunity to suit. $\mathrm{He}$ also moved to strike the counterclaim of the other defendants. ${ }^{x}$

Judgment of the trial court granting a declaratory judgment as requested by the defendants was entered on January I6, I948.20 The Secretary of State's motion to strike the complaint was sustained on the ground that "there is no such established political party as the Progressive Party" but was denied on the jurisdictional grounds. The Progressives immediately filed notice of appeal directly to the Tllinois Supreme Court ${ }^{2 x}$ asking for a reversal of the judgment, retroactive to January 26 in order to permit compliance with the filing requirements.

On appeal the defendants relied upon two provisions of Article 7 as denying to the Progressive Party a right to participate in the April primary: Section 2, which defines a political party entitled to use the primary mechanism in terms of the vote received at the last general election for state and county officers, and Section Io, which defines signature requirements in terms of the number of voters at the last general election. Both of these provisions are subject to the definitions of "election" and "general election" found in Section 4 of Article 7, which specifically exclude elections for judges only.

In their argument before the Supreme Court, the plaintiffs maintained that they had qualified as an established political party within the meaning of Article Io. The restrictive definition of 'general election' found in Article 7 is, by its own terms, not applicable to Article ro, ${ }^{2}$ and an examination of the legislative his-

17 Plaintiff's Abstract, at I $1-12$.

${ }^{18}$ Ibid., at 24-32.

2x Direct appeal to the State Supreme Court is a matter of right where a franchise or a constitutional question is involved. Ill. Ann. Stat. (Smith-Hurd, r948) c. rro, § r99.

${ }^{22}$ Consequently the definition of "general election" applicable to Article ro is that found in Article I, $\delta 3$ of the Election Code: " 'General election' means a regular election for the choice of a national, state, judicial, district, or county officer." "Regular election" was defined in Elder v. Quilici, 309 Ill. App. 466, 468, 33 N.E. 2d 492, 494 (194r), as one which recurs at stated intervals as fixed by law. 
tory of the latter article reveals no intention to exclude judicial elections from that category of elections which could be used as the basis for establishing a new party. ${ }^{23}$ But of greater importance was the fact that the restrictive definition of "general election" found in Section 4 of Article 7, was added as an amendment in 1936 for the sole purpose of permitting coalition judicial tickets in Cook County under the Democratic Party label without thereby depriving the Republican Party of its status as an established political party in Cook County. ${ }^{24}$ Any doubt as to the actual purpose of the amendment is removed by the emergency clause attached to the bill itself which unequivocally states the reason for its passage. ${ }^{25}$

The plaintiffs then argued that while there was an apparent conflict between Articles 7 and Io as to the definition of an established political party, in fact the definition found in Section 2 of Article Io, is the only one applicable to the establishment of a new party. The definition in Article 7 is relevant only with regard to the conditions under which an established party may become disestablished. In other words, it sets up the standards which an already established party must maintain. ${ }^{26}$ Thus, the legislature intended that a new party might become established at any election, but could lose that status only by failing to receive the required percentage of votes at an election other than one for judges exclusively. ${ }^{27}$

The defendants (other than the defendant Secretary of State) moved to transfer the cause to the Appellate Court on the grounds that neither a franchise nor a constitutional question was involved, but merely the construction of a statute. In their answer on the merits, the defendants contended that the Progressives simply did not meet the requirements of Article 7 because they had not received five per cent of the vote at the last general election within the meaning of that Article. They maintained that where the words of a statute are clear the legislative intent is not to be examined, and that here there was really no ambiguity. Article Io, they said, must be read in conjunction with

${ }^{23}$ Progressive Party v. Flynn, 400 III. I02, 79 N.E. 2d 5 I6 (I948), appellant's brief, at 2I-29.

24 Proclamation of the Governor, House Journal, 59th Gen. Assembly, 3 d Spec. Sess. at 4 .

2s Ill. L. (1936), 59th Gen. Assembly, 3d Spec. Sess., at 9.

${ }^{26}$ Appellant's brief, at 40 .

${ }^{27}$ Appellant further argued that if Article 7 be construed so as to deprive the Progressive Party of the right to participate in the primary even though it had qualified as an established political party under Article to, then appellant was being deprived of constitutional rights. The right to nominate and vote for candidates of one's own choosing was alleged to be a right reserved to the people by the Ninth and Tenth Amendments to the United States Constitution, and the primary election, in which candidates for the United States Congress are involved, is an election within the meaning of Sections 2 and 4 of Article I. Consequently the fact that Article 7 discriminates against voters desiring to form a new party and in favor of established parties makes it violative of the equal protection and due process clauses of the Fourteenth Amendment. Progressive Party v. Flynn, 400 Ill. I02, 79 N.E. 2d 5I6 (I948), appellant's brief, at 5 I. 
Article 7 , and when that is done the result is to remove judicial elections from the category of elections at which new political parties can become established. ${ }^{28}$ They alleged, furthermore, that this was neither an unreasonable nor unconstitutional impairment of the franchise: A party might still become established at the bi-annual congressional elections, or in any case could get on the November ballot via the petition method of Article ro.

The defendant Secretary of State, acting through the Attorney General, filed a brief asking for affirmance of the trial court's decision granting his motion to strike the complaint. The Attorney General argued that equity had no jurisdiction to enjoin, control, or interfere with elections, or to determine political issues or protect political rights. Moreover, he urged, a declaratory judgment is similar to injunction, not to mandamus, and hence is not an appropriate means for the protection of political rights. ${ }^{29}$

The decision in Progressive Parly v. Flynn ${ }^{30}$ was handed down on April 7, I948, six days before the scheduled primary. The defendants' motion to transfer to the Appellate Court was denied, and the court then adjudged the Progressive Party to be an established political party in Cook County, stating: "This amendment (i.e., the definition found in Article 7, Section 4) does not apply and was not intended to apply to a political party entitled to nominate because it became such as a result of provision of section 2 of article ro." ${ }^{3}$ No opinion as to the efficacy or character of consequential relief was given.

Pursuant to this mandate the Circuit Court set aside its order of January r6 and declared that the Progressive Party had the right to nominate candidates in the primary. But on April 9 the Circuit Court orally denied a motion of the Progressive Party asking for an order requiring the defendants to print appropriate ballots. On April $x 2$ a written order to the same effect was issued, the court judicially noticing that it would be physically impossible to comply in time. ${ }^{32}$

After the primary election, the Progressive Party found itself in an unenviable position with respect to its prospects of placing candidates on the ballot in

${ }^{28}$ Ibid., appellee's brief, at 20.

${ }_{29}$ This provided appellants with an opportunity to lecture the Attorney General on the powers of a court of equity and the nature of a declaratory judgment. A declaratory judgment is, of course, a proceeding sui generis, and consequently the alleged limitations on the powers of a court of equity are irrelevant. Borchard, Declaratory Judgments 239-40 (2d ed., 194I). In any event, equity is concerned with coercive remedies, and a declaration of rights is all that was sought here, although paragraph (3) of the Illinois Declaratory Judgments Act, note I6 supra, does authorize application for further remedies where necessary. Declaratory judgment is a particularly appropriate means for the enforcement of political rights. Borchard, supra, at 868. Appellants further contended that the often stated proposition that equity has no jurisdiction to enforce political rights is not a correct statement of the law. See note 89 infra; Progressive Party v. Flynn, 400 Ill. 102, 79 N.E. 2d $5^{16}$ (1948), appellant's reply brief, at $7-22$.

${ }^{30} 400$ Ill. I02, 79 N.E. 2 d 516 (I948). $\quad{ }^{31}$ Ibid., at 52r.

${ }^{32}$ Progressive Party v.Flynn, 82 N.E. 2 d 476 (IIl., I948), Defendants' Flynn, et al., Abstract of Record, at 4I. Hereinafter referred to as Defendants' Abstract. 
November. Having been declared to be an established political party in Cook County there was no longer available to it the method of nomination by petition prescribed in Article ro of the Election Code. ${ }^{33}$ On the other hand, it had been unable, through no fault of its own, to take advantage of the only other available mechanism of nomination-the primary election. It sought for some method of getting on the November ballot and decided to make use of the provisions for the filling of vacancies in nominations found in Section 6I of Article 7.34 Accordingly, the Managing Committee of the Party and various subcommittees appointed by it selected candidates for the offices within Cook County and subdivisions thereof. Certificates of nomination and statements of candidacy were presented to the appropriate public officials, who declined to accept them. The Party, relying on the decision in Progressive Party v. Flynn, twice petitioned the State Supreme Court, requesting that Court to exercise its original jurisdiction in mandamus to compel the officials to receive the certificates. In each case the Supreme Court, without opinion, declined to act, presumably because it felt that certain factual questions were involved which should be determined by a lower court.

The Progressives on May 28 petitioned the Circuit Court of Cook County for an order directing the various defendants to show cause why further relief in the nature of mandamus compelling the defendants to accept the nominating papers that had been tendered for the various "vacant" offices should not be granted. ${ }^{35}$ This action was predicated upon paragraph (3) of the Declaratory Judgments Act, which makes provision for further remedies of a coercive nature where necessary. ${ }^{36}$

The petitioner alleged that respondent's refusal to act effectively deprived it of its rights as an established political party in Cook County and deprived its members of their franchise. ${ }^{37}$ The defendant Secretary of State filed a motion to strike the petition ${ }^{38}$ and the other defendants did likewise, ${ }^{39}$ alleging that there can be no vacancy in a nomination until a nomination has been made, and that even if such vacancy did exist the Managing Committee would be

33 Art. Io, § I provides: "[N]o nominations ... may be made under the provisions of this Article ro by any established political party which at the general election next preceding, polled more than five (5) per cent of the vote cast . . . in the electoral district for which the nomination is made..." The decision in Progressive Party v. Flynn, 400 Ill. Io2, 79 N.E. 2d 516 (I948), had established that the judicial election of November 1947 was a general election.

${ }^{34}$ "In case a candidate who has been nominated under the provisions of this Article 7 shall die before election... or should the nomination for any other reason become vacant, the managing committee ... of the respective political party for the territorial area in which such vacancy occurs, shall nominate a candidate or candidates of the respective party to fill such vacancies on the ticket." Art. $8, \S$ I 7 contains a similar provision applicable to candidates for the state legislature, and such candidates were nominated by Progressive Party Committeemen.

${ }^{35}$ Defendants' Abstract, at $4 \mathrm{I}$.

${ }^{36}$ Ill. Ann. Stat. (Smith-Hurd, I948) c. I10, § I81.I(3). $\quad 3^{8}$ Ibid., at 60.

37 Defendants' Abstract, at 57 .

39 Ibid., at $6 \mathrm{I}$. 
powerless to fill it since the statutory authority of that Committee had expired with the April primary.

The final order of the Circuit Court issued on June 8 accepted in substance petitioner's contentions and authorized them to place names on the November ballot by virtue of the vacancy provisions of Section 6I of Article 7 and Section I7 of Article $8.4^{\circ}$ Each of the defendants was separately ordered to perform all of the acts within the scope of his authority to the end that Progressive Party candidates might appear on the Cook County ballot in November. The respondents (other than the Secretary of State) immediately filed an appeal to the Appellate Court asking for reversal. At the same time, the Attorney General, purportedly acting on behalf of the Secretary of State, appealed directly to the State Supreme Court, also asking for reversal. The Progressive Party filed a cross appeal in the Supreme Court asking that certain language of the trial court be amended so as to remove the possibility of future uncertainty.

At this stage of the proceedings Attorney General George F. Barrett parted company with his statutory client, Secretary of State Edward J. Barrett. Secretary Barrett requested that he be permitted to join the other defendants in the Appellate Court proceedings, and entered his appearance there pro se..$^{4 \mathrm{I}}$ The Attorney General, nevertheless, insisted upon his exclusive right to "defend" the Secretary of State and proceeded to file briefs and arguments in his behalf in the Supreme Court.42

The rather unusual situation which followed from the difference of opinion between the two state officers is explainable only in light of Illinois politics. At the time of the action, all of the state officials including the Attorney General were members of the Republican Party. The one exception was the Secretary of State, a Democrat. The Cook County defendants were for the most part Democratic. During the summer it became apparent to the Republicans that the presence of the Progressive Party on the ballot would serve to draw voting strength away from the Democrats, a result to which they would hardly be averse. The Democrats, however, had equally good reason to wish the Progressives kept off the ballot.43

$40 \mathrm{Ibid}$., at 64 . The accompanying oral opinion indicates that the court's decision was predicated less upon the actual merits of the statutory construction argument than upon general equitable principles. "The time element alone prevented the party from appearing on the ballot at the primary. To hold that they were not able to nominate by their party machinery would be to state that they were given a right without a remedy." Ibid., at ro3.

4 Ibid., at 88.

${ }^{2}$ It should be noted that the duties which the petitioner was seeking to compel the various defendants to perform were separate and distinct from one another, and the trial court's order had been directed to each of the defendants individually. The Secretary of State had statutory duties only with respect to candidates for Congress and for Representatives in the General Assembly. Hence there was nothing to prevent the Secretary of State from conducting his suit apart from the other defendants.

43 The actual results of the November 2 elections indicate that the Republican hopes and the Democratic fears were in vain. All Democratic candidates for state offices won by such large margins that it is extremely unlikely that the presence of Progressive Party candidates 
Following the Circuit Court's order of June 8, the Progressives were naturally desirous of obtaining a final adjudication by the State Supreme Court in order to avoid any difficulties which might arise from the physical impossibility of printing ballots in a short time. The Attorney General was quite willing to concur with this objective. The other respondents (including the Secretary of State appearing pro se) maintained that no constitutional issue or franchise was involved in this appeal, and consequently the Supreme Court had no jurisdiction on direct review.

On July $\mathrm{I}$, the defendant-appellants in the Appellate Court moved that court for an order of supersedeas, and on July I9, after argument, the motion was granted and the Notice of Appeal made to serve as a supersedeas suspending execution of the trial court's judgment.44 At the same time, appellee appeared specially in the Appellate Court and moved to transfer the cause to the Supreme Court, arguing that the Appellate Court had no jurisdiction over the cause. After denial of this motion, the Party filed a motion in the Supreme Court asking for leave to file a petition for that Court's auxiliary process to compel transfer of the cause and for expunction of the supersedeas.

The motion was granted on August I9 and the petition immediately filed. The Progressives maintained that the appeal did involve both a franchise and constitutional issues 45 and hence the Supreme Court had exclusive jurisdiction. Consequently the supersedeas issued by the Appellate Court would be coram non judice and void. The Attorney General, still purportedly acting for the Secretary of State, answered the petition and strongly supported it, devoting considerable attention to justifying his rather unusual status in the proceedings. ${ }^{46}$

The other defendants appeared specially in the Supreme Court to contest

on the ballot would have altered the result even if all their votes had been drawn from the Democratic ticket. See Official Vote of the State of Illinois Cast at the General Election November 2, 1948 (Office of the Secretary of State, Springfield).

44 Ill. Ann. Stat. (Smith-Hurd, r948) c. Iro, \& 206(3).

45 The Progressive Party's petition for a rule to show cause had alleged that a refusal to place the party on the ballot would deprive its members of constitutional rights guaranteed by Article II, $\S 4$, and the Fourteenth Amendment to the United States Constitution, and Article II, $\$ \S 2$, I8, rg of the Illinois Constitution. Defendants' Abstract, at 57.

${ }_{4}^{6}$ "'[W]hile the Attorney General represents the Secretary of State in his official capacity and is indeed his only advisor and sole legal representative in the courts and elsewhere, he is under no duty whatsoever-to assist such public official in concealing from this Court the situation relating to its jurisdiction or that of the Appellate Court, and, on the contrary, as the chief law officer of the people and as an officer of this Court, he is under a duty to the people of the State of Illinois and to this Court to present the considerations which lead him irresistibly to the conclusions that, a franchise and constitutional questions necessary (sic) being involved, this Court has exclusive jurisdiction. ..." (italics in original). Progressive Party v. Flynn, 82 N.E. $2 \mathrm{~d} 476$ (IIl., I948), Answer of Defendant E. J. Barrett, Secretary of State, by George F. Barrett, Attorney General, at 5. For further discussion of the manner in which the Attorney General has performed his duty to the People of Illinois, see Katz, An Open Letter to the Attorney General of Illinois, ${ }_{5}$ Univ. Chi. L. Rev. 25I (I948); editorials in the St. Louis PostDispatch: p. 2B, col. 3 (Oct. 7, I948); p. 2C, col. 3 (Oct. 22, 1948); p. 2C, col. 2 (Oct. 24, 1948); p. $2 \mathrm{~B}$, col. 3 (Oct. 25, x948); p. 2C, col. 2 (Oct. 27, 1948). 
the petition, and argued that no constitutional question was presented for review inasmuch as the final order of the trial court had been rendered on other issues-namely, the construction of the vacancy provisions of the Election Code. Nor is a franchise involved, they contended, since the case does not concern the right to vote but merely the regulation of the manner in which the vote is to be cast. 47

The Supreme Court granted the petition of the Progressives on September 7. The supersedeas was expunged and the entire cause transferred to the Supreme Court. With all parties face to face at last, briefs were filed and argument completed shortly thereafter. Since no decision was rendered by the court prior to the election, the ruling of the Circuit Court remained in effect and the Progressive Party was able to appear on the November ballot in Cook County. ${ }^{4}$ On November I8 the Illinois Supreme Court affirmed the judgment of the Circuit Court, holding that the Progressives were entitled to make use of the vacancy provisions of the Election Code because any existing office without an incumbent is vacant. "There is no basis for the distinction that [the word "vacancy'] applies only to an office vacated by death, resignation or otherwise." 49 Furthermore, the court held that the Managing Committees of the Party did have authority to fill the vacancies.

The brief filed by the Attorney General on behalf of the Secretary of State raises an important question. The Attorney General listed twelve "errors relied upon by Edward J. Barrett, Secretary of State" $5^{\circ}$ and proceeded to set forth the arguments in favor of each. But in each case he concluded that the arguments were untenable as a matter of law and ought to be rejected. The conclusion of the Attorney General's brief is worthy of quotation in full: ${ }^{5 x}$

The Attorney General having, as attorney for Edward J. Barrett, Secretary of State, herewith presented every possible ground for reversal which could be urged by said appellant, but, under his higher, greater, and paramount duty to the people, having as attorney for the people of the State of Mlinois, likewise presented the contrary considerations which lead him irresistibly to the conclusions that the plaintiffs were and are entitled to all of the relief which they sought and were granted below and that the order of the trial court, from which this appeal has been prosecuted, was and is wholly without error; - prays that this Honorable Court consider the matters and things raised by this appeal and affirm the judgment below..$^{22}$

47 Defendants' Reply to Petition, at 7-r6.

${ }^{48}$ Following the expunction of the supersedeas by the Supreme Court, the defendant County Clerk reluctantly conceded that he would place the Progressives on the Cook County ballot, reportedly commenting: "I'm not going to jail for anybody." Chicago Sun-Times, p. 2, col. 3 (A.M. ed., Sept. 8, r948).

49 Progressive Party v. Flynn, 82 N.E. 2d 476, 48I (IIl., I948).

50 Brief for Attorney General as Attorney for Secretary of State, at 17.

5 Ibid., at 46.

52 Koko: Now, as my Solicitor, how do you advise me to deal with this difficulty? PоOH-BAH: Oh, as your Solicitor, I should have no hesitation in saying "chance it-." Koko: Thank you, I will. 
The other defendants (including the Attorney General's client, the Secretary of State) professed astonishment at this course. They were unable to understand how a new client-namely, the People of the State of Mllinois-had suddenly made an appearance in the proceedings, and they filed a formal objection to the tactics of the Attorney General "which seriously prejudiced their cause." They further urged that the Attorney General by now asking for affirmance had abandoned his appeal and consequently should have no standing in the case at all. This argument was summarily rejected by the Illinois court on the ground that once jurisdiction had attached to the court it could not be divested by a concession of one of the parties concerning the rights of the other. ${ }^{54} \mathrm{But}$ in adopting this view the court stressed the fact that the other defendants had failed to cite any authority in support of their contentions.

Proceedings in which the Attorney General presents the arguments for both parties, while unusual, are not unprecedented. .5 What was unique in the instant case was the fact that the arguments of both sides were presented in the same brief. Apparently the Attorney General felt it necessary to set forth the arguments for reversal, arguments which he rejected, in order to avoid the consequences of those decisions which hold that an appeal is abandoned where the appellant presents no argument in its support, or appears only as respondent. ${ }^{56}$ On the other hand, there is more authority for the proposition that where the Attorney General is confronted by conflicting duties he must perform only that duty which is most in accord with the public interest. ${ }^{57}$ In the instant case it would seem that his duty to his statutory client was paramount since the arguments on behalf of the Progressives were to be presented to the court in any

Poom-BAE: If it were not that, as Lord Chief Justice, I am bound to see that the law isn't violated.

Koко: I see. Come over here where the Chief Justice can't hear us. Now, then, as First Lord of the Treasury?

Poo-BAH: Of course, as First Lord of the Treasury, I could propose a special vote that would cover all expenses, if it were not that, as Leader of the Opposition, it would be my duty to resist it, tooth and nail. Or, as Paymaster-General, I could so cook the accounts that, as Lord High Auditor, I should never discover the fraud. But then, as Archbishop of Titipu, it would be my duty to denounce my dishonesty and give myself into my own custody as First Commissioner of Police.

Koko: That's extremely awkward.

Gilbert and Sullivan, The Mikado, Act I.

53 Defendants' Reply to Petition, at 20-22.

54 Progressive Party v. Flynn, 82 N.E. 2d 476, 480 (Ill., I948)،

s5 See Reiter v. Wallgren, 28 Wash. 2d 872, I84 P. 2d 57r, 575 (r947); cf. Attorney General v. Hunt, 59 Ariz. $256,258,126$ P. $2 \mathrm{~d} 303,304$ (r942), vacated on rehearing 59 Ariz. 312,127 P. $2 \mathrm{~d} 1_{30}$ (1942).

${ }^{56}$ Hilmes v. Moon, r68 Wash. 222, Ir P. 2d 253 (1932); Fields v. Sanders, 29 Calif. 2d 834, I80 P. 2d 684 (x947).

57 Marsh v. Aljoe, 4I Wyo. II9, 282 Pac. I055 (I929); Attorney General v. State Board of Equalization, x40 Wash. 433, 249 Pac. 996 (I926); Frohmiller v. Hendrix, 59 Ariz. I84, I24 P. $2 \mathrm{~d} 768$ (I942). 
event by their own counsel..$^{8}$ Certainly this should be the case where no formal demand has been made upon the Attorney General for his services on behalf of the people.59

In Illinois, the Attorney General is the sole representative of state officials. ${ }^{60}$ That being the case, it is usually held that any state official who disagrees with the manner in which the Attorney General is conducting his defense may conduct his own defense, provided that no additional expense is thereby caused the state. ${ }^{6 x}$ Under such circumstances the Attorney General should not be permitted to carry on a separate defense in the name of the official. ${ }^{62}$

Several conclusions may be drawn from this examination of the course of Progressive Party litigation in Tllinois which would seem to have general application to any statutory provisions respecting minority political parties. Most obvious is the fact that "politics" must inevitably play a large role in the proceedings. Since the public officials representing the state will always be members of one or the other major party, the strategic decisions, including the choice of dilatory tactics, will be made not merely with a view toward winning the case itself but rather in the light of their effect upon that party's chances of winning the election. The difficulty is somewhat ameliorated by the fact that the two major parties may have divergent views toward the presence of a new party, but in any event the interests of the public and of the new party as well, are likely to be lost sight of in the process.

Secondly, this litigation, as well as the subsequent Progressive Party case in the federal courts, discussed hereafter, clearly emphasizes the importance of the time element in this type of proceeding. No cause of action can accrue to the new party until it appears that an effort will be made to keep it off the ballot, and this will necessarily be very near election time. Once the election has passed, the party is in a position only to claim damages for deprivation of the right to vote, at best a small consolation..$^{63}$

${ }^{8}$ Marsh v. Aljoe, 4I Wyo. II9, 282 Pac. I055 (I929); cf. Reiter v. Wallgren, 28 Wash. 2d 872, I84 P. 2d 57 I (1947).

s9 Reiter v. Wallgren, 28 Wash. 2d 872, 184 P. 2d 57I (x947). But cf. Attorney General v. State Board of Equalization, r40 Wash. 433, 249 Pac. 996 (I926) (Attorney General's paramount duty is the protection of the interests of the people, and where he is cognizant of violations by a state officer his duty is to obstruct and not assist).

60 Fergus v. Russell, 270 Ill. 304, 337, xro N.E. 130, I45 (1915).

6x Frohmiller v. Hendrix, 59 Ariz. I84, I24 P. 2 d 768 (1942); Amerland v. Hagen, 44 N.D. 306, 175 N.W. 372 (r919); see Piccirilli Bros. v. Lewis, 282 Penn. 328, 336, I 27 Atl. 832, 835 (r925) (may employ private counsel at own expense to present views but such counsel may not appear of record).

62 Frohmiller v. Hendrix, 59 Ariz. 184, r24 P. $2 d 768$ (I942); Amerland v. Hagen, 44 N.D. 306, I75 N.W. 372 (rgrg).

${ }^{6}$ See Blackman v. Stone, I7 F. Supp. ro2 (IIl., I936), vacated on ground of mootness 300 U.S. $64 \mathrm{x}$ (I936). In later proceedings for damages for deprivation of the right to vote, the constitutional question was for the first time considered on the merits and then only by way of dictum. Blackman v. Stone, ror F. 2d 500 (C.C.A. $7^{\text {th, I939). }}$ 
Of even greater importance, perhaps, these proceedings emphasize the fact that statutory provisions relating to new parties, because used so seldom, are likely to be difficult to handle when the occasion does arise, and may even present unforeseen contradictions. At the very least, they will provide the defendants with many opportunities to employ procedural moves of a dilatory nature. Since time is always working strongly against the minority party, it is important that a clear-cut interpretation of the statute be had in advance of any attempt to make use of it. Yet this is impossible, even where a declaratory judgment act is in effect, and the only remedy appears to be good draftsmanship, an attribute notably lacking in many state legislatures. Finally, these cases definitely sanction the use of the declaratory judgment as a device for the determination of political and constitutional questions, thus making available the only means by which a new party can even hope to surmount the obstacles presented by the shortness of time. ${ }^{64}$

\section{II}

Concurrent with the Cook County litigation the Progressive Party began its efforts for a state-wide place on the ballot and for the opportunity to run candidates for President, Vice-President, United States Senator, and for all statewide offices. ${ }^{65}$ During the summer the party circulated petitions bearing the names of twenty-eight presidential electors and candidates for various statewide offices, and filed them in accordance with the statute, which requires a total of twenty-five thousand signatures including at least two hundred from each of fifty counties. Objections were presented, and in accordance with Article ro, Section ro of the Election Code, the State Officers Electoral Board met

${ }_{4}$ Certain language of Justice Frankfurter in Colegrove v. Green, 328 U.S. 549 (1946), indicated that a declaratory judgment would be proper only in a case where an injunction could be had. See Applicability of Limitations on the Use of the Injunction in Constitutional Litigation to the Federal Declaratory Judgment, 35 Calif. L. Rev. 252 (r947); Need for In-

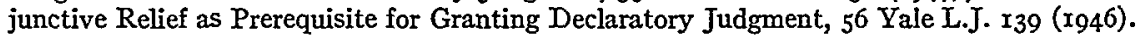
MacDougall v. Green, 335 U.S. 28I (I948), indicates that the Supreme Court has now abandoned that proposition. However, the case is not conclusive since injunctive relief was requested along with the declaratory judgment.

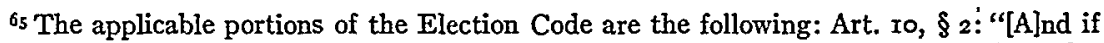
such new political party shall be formed for the entire state, [the petitions] shall be signed by not less than twenty five thousand $(25,000)$ qualified voters: Provided, that included in the aggregate total . . . are the signatures of two hundred (200) qualified voters from each of at least fifty (50) counties within the State." Art. Io, $\$ 4$ provides that the signers of petitions must be registered voters who have not voted at a primary held to nominate candidates for any of the offices to which the petition is applicable. Art. ro, $\$ \S 6,8$ state that the petitions are to be presented to the State Certifying Board, consisting of the Governor, Secretary of State, and State Auditor, and shall be deemed valid unless objected to by any legal voter within five days after the last day for filing. Art. Io, $\$ \S 9$, Io provide a procedure for the hearing of objections to petitions. The Secretary of State, Auditor of Public Accounts, and Attorney General shall constitute themselves as the State Officers Electoral Board to hear and pass upon objections. In the event that any of these members are also candidates for the offices in question, they shall be replaced by Justices of the State Supreme Court. The Electoral Board is invested with the power to subpoena records, compel testimony, and administer oaths. 
in the Capitol Building at Springfield on August 26 to conduct hearings on the petitions. $^{66}$

In the course of the hearings the objectors conceded that the petitions contained over twenty-five thousand valid signatures and that the two-hundredsignature requirement had been satisfied in forty-one of the necessary fifty counties. They conceded that the petitions lacked only a total of from eightythree to one hundred and ten signatures, distributed among nine counties. The Progressive Party maintained that the objectors had failed to prove that the requirements were not satisfied in sixty-two counties. ${ }^{67}$

On August $3^{\mathrm{I}}$ the Board issued its decision, finding as a matter of fact that the petitions did not bear two hundred valid signatures from each of fifty counties, and hence the Progressive Party was not entitled to have its candidates appear on the November ballot outside of Cook County. ${ }^{68}$ Subsequently, on Sep-

${ }^{66}$ Since the Progressives were running candidates for Secretary of State and Attorney General, those two officers retired from the Electoral Board and were replaced by Justices Gunn and Wilson of the Illinois Supreme Court. The third member of the Board was the State Auditor. But before the composition of the Electoral Board was finally determined there took place a ludicrous series of maneuvers which well illustrates the atmosphere in which the entire litigation was conducted. Although the Electoral Board is presumably an impartial factfinding body, the Democrats were keenly desirous of constituting a majority, and the Republicans and Progressives were equally anxious to have a Republican majority. Originally, the Progressives had nominated candidates for Secretary of State and for Attormey General, thus

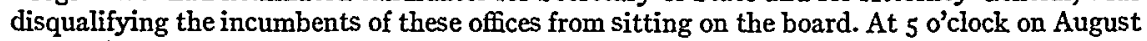
2I, the last day upon which a candidate was permitted to withdraw, the Progressive candidate for Secretary of State suddenly withdrew from the contest. This would have permitted the Democratic Secretary of State, E. J. Barrett, to resume his place on the board, while at the same time it would be too late for the Progressives to withdraw their candidate for Attorney General in order to permit Republican G. F. Barrett to return. The Progressives instead nominated a new candidate for Secretary of State under the vacancy provisions of Art. Io, $\$ 8 \mathrm{II}$ and $\mathrm{I2}$ of the Election Code, and the certificate of nomination was promptly signed by the two Republican certifying officers, the Governor and State Auditor. The third certifying officer, Secretary of State Barrett, refused to sign the certificate, claiming that it was legally impossible to fill the vacancy. MacDougall v. Green, 80 F. Supp. 725 (Ill., I948), Complaint, exhibit B. The Progressives then obtained a restraining order from the Sangamon County (Springfield) Circuit Court, forbidding Barrett to sit on the Board. This was followed by a permanent injunction having the force of mandamus. Justice Gunn replaced Barrett, but the latter still failed to sign the nominating certificate. After the issuance of an impounding order, the Secretary "lost" the certificate and it was never recovered. The Progressives then made an unsuccessul attempt to have the Secretary jailed for contempt. MacDougall v. Green, ibid., Complaint, exhibit C.

${ }^{67}$ Detailed statistics of the respective contentions will be found in MacDougall v. Green, 80 F. Supp. 725 (Ill., 1948), Complaint, exhibits E and F. Most of the discrepancies arose from the fact that signers of the petitions were later discovered to have voted at the primary or to be unregistered and hence disqualified. The Progressives were, of course, unable to obtain new signatures to replace those disqualified since the deadline for filing of petitions, seventy-eight days before the general election, had already passed. Election Code Art. Io, §6 (Supp., I948).

${ }^{68}$ MacDougall v. Green, 80 F. Supp. 725 (Ill., I948), Complaint, exhibit D. The Election Code makes no provision for appeal from the decision of the Electoral Board. The Progressive Party might conceivably have chosen to carry on their fight along the line that there is a constitutional right to judicial review of the Board's decision. Apart from other considerations, the shortness of time remaining until the election made this course impractical. Only questions of fact were involved in the Board's decision, and no court would be likely to upset the findings of fact when two Justices of the State Supreme Court were sitting on that board. 
tember I3 and September 23, the Progressive Party made two separate motions in the State Supreme Court to obtain leave to file petitions for mandamus in that Court. They sought to obtain an adjudication of the constitutionality of the r935 Amendment to Section 2 of Article ro of the Election Code which provides for the geographical distribution of signatures, and in each case the motion was denied without opinion. The Party did not attempt to obtain certiorari from the United States Supreme Court to review these rulings in view of that Court's decision in White $v$. Ragen, ${ }^{69}$ but instead on September 24 filed a complaint in the United States District Court asking for a declaratory judgment and injunctive relief. The three state officers who, under Section 6 of Article ro, were charged with the duty of certifying the names of candidates were named as defendants together with various county and municipal election officials. ${ }^{70}$

The plaintiff alleged that the I935 Amendment which added the signature distribution requirement to the then existing provisions for nominations by the petition method ${ }^{7 x}$ was unconstitutional as constituting an arbitrary, unreasonable, and discriminatory restriction on the right of qualified voters to nominate and vote for candidates of their own choice, in violation of Sections 2 and 4 of Article I, and Amendment XIV of the United States Constitution, and Article II, Section I8 of the Illinois Constitution.

The jurisdiction of the District Court was predicated upon Section 1343(3) of the new Judicial Code. ${ }^{72}$ The cause was heard in Chicago by a three-judge District Court under authority of Section 228I of the Judicial Code, and a decision rendered on October II denying the motion for an interlocutory injunction and dismissing the complaint on the grounds that the r935 Amendment was not repugnant to the United States or Illinois constitutions. ${ }^{73}$

Direct appeal to the Supreme Court is a matter of right where a three-judge District Court is involved. ${ }^{74}$ That Court, in view of the imminence of the election, granted appellant's motion to advance and expedite the hearing. Briefs were submitted, oral argument heard on October I8, and a decision handed down on October ${ }_{21}, 75$ a remarkable example of the Court's willingness to ac-

${ }^{69} 324$ U.S. 760 (I945).

${ }_{70}$ The three members of the State Officers Electoral Board, the body which had invalidated the nominating petitions, were not named as defendants since no relief was requested against them. MacDougall v. Green, 335 U.S. 28I (I948), Appellant's Supplemental Memorandum at 2.

${ }^{72}$ Election Code Art. ro, $\$ 2$. If this amendment had been invalidated the Election Code would have remained in effect as it was before 1935-that is, without the signature distribution requirements but with the same overall signature requirements. Cf. Rippinger v. Niederst, 317 Ill. 264, 272, 148 N.E. 7, ro (r925); People v. Butler Street Foundry, 20r Ill. 236, 257, 66 N.E. 349,356 (I903).

$7^{2}$ "The District Court shall have original jurisdiction of any civil action. ... (3) To redress the deprivation under color of any State law, statute . . . or usage, of any right, privilege or immunity secured by the Constitution of the United States. ..." 28 U.S.C.A. § I343(3) (Supp., I948).

73 MacDougall v. Green, 80 F. Supp. 725 (Ill., I948).

7428 U.S.C.A. $\S$ I253 (Supp., I948). $\quad{ }_{75}$ MacDougall v. Green, 335 U.S. 28I (I948). 
commodate itself to the requirements of an emergency situation. The appellant argued that in view of the short time remaining until the election all conceivably effective state remedies had been exhausted, but that in any event a preliminary expedition to the state courts was not required..$^{76}$ In support of their contention that the statute was arbitrary and unreasonable, the Progressives pointed out that the forty-one counties in which the petitions were admittedly valid contained eighty per cent of the state's population. Yet even if all the inhabitants thereof desired to form a new party, they could not do so. Eighty-seven per cent of the population residing in the forty-nine most populous counties could not do so. On the other hand, the thirteen per cent of the population residing in the fifty least populous counties would be able to establish a new party. ${ }^{77}$ It was pointed out that a geographical distribution requirement exists nowhere else in Illinois election law.

The appellant contended that the law discriminated in a twofold manner: against the voters in the more populous counties and in favor of those in less populous areas, and against those voters who wish to form a new party and in favor of members of established parties who are subject to no geographical distribution requirements. Furthermore, it was argued, this discrimination fits into the general pattern of political power in Illinois-a pattern of downstate control-evidenced most conspicuously in the loing fight over reapportionment. ${ }^{78}$

The Progressives contended that the I935 Amendment violated the privileges and immunities clause of the Fourteenth Amendment as follows:79 The right to vote for federal officers is a right protected by the United States Constitution.80 Where a primary is an integral part of the electoral process it is protected by the Constitution. ${ }^{8 \mathrm{x}}$ The right to nominate candidates for federal office by primary is an integral part of the electoral process. ${ }^{82}$ Nomination by petition is analogous to nomination by primaryand is so recognized in the Illinois Election Code. Therefore, the right to nominate federal officers by petition is protected by the United States Constitution. The Illinois statute in question is an abridgment of that right since it deprives even a majority of qualified voters of the opportunity to nominate candidates by petition unless they meet the distribution requirements. Moreover, because of the discrimination described above, the statute also violates the equal protection clause just as did the "white primary" laws struck

${ }^{76}$ Citing Lane v. Wilson, 307 U.S. 268, 274 (I939).

77 Appellant's brief, at 24 .

$7^{8}$ See Colegrove v. Green, 328 U.S. 549 (1946), noted in 56 Yale L.J. 127 (1946); 4I Ill. L. Rev. 578 (1946); 45 Mich. L. Rev. 368 (1947). Appellants contended that the failure of Illinois to apportion congressional districts deprived them of constitutional rights because their vote was less influential than that of residents of less populous districts. The merits of the constitutional question were not decided.

79 Appellant's brief, at 29.

${ }^{80}$ Ex parte Yarbrough, I Io U.S. 65I (I884); Smith v. Allwright, 32 I U.S. 649 (I944).

8x United States v. Classic, 313 U.S. 299, 3 I6 (I94I).

${ }^{82}$ Breckton v. Election Commissioners, 22 IIl. 9, 18, 77 N.E. 32I, 323 (1906). 
down in Nixon v. Herndon, ${ }^{83}$ Nixon v. Condon, ${ }^{84}$ Smith v. Allwright, ${ }^{85}$ and Rice v. Elmore. ${ }^{86}$ Appellants then contended that if the I935 Amendment was unconstitutional as applied to candidates for federal office, namely United States Senator, it must fail in its entirety. ${ }^{87}$

The Progressives urged additionally that the provisions in question violated the Seventeenth Amendment to the United States Constitution and Section I8 of Article III of the Illinois Constitution. ${ }^{88}$ In conclusion appellant maintained that the Court could enter an effective order granting the requested relief, thus eliminating the issue that proved decisive in Colegrove v. Green. ${ }^{89}$ Clearly the crucial question in the Progressives' argument was whether or not the geographical distribution requirement was in fact arbitrary or unreasonably discriminatory. The Assistant State's Attorney of Cook County, representing some of the defendants, argued that it was not. Attorney General Barrett, this time representing the defendant certifying officers, appeared before the Court, confessed error, and asked for reversal.

The decision of the Supreme Court, per curiam, in MacDougall v. Green,90 was joined in by five justices. Justice Rutledge concurred on the sole ground that equity could not enter an effective order. ${ }^{9 x}$ Justices Douglas, Black, and Murphy dissented. The Court found no violation of the Fourteenth Amendment in the Illinois election law. "It would be strange indeed, and doctrinaire for this Court, applying such broad constitutional concepts as due process and equal protection of the laws, to deny a State the power to assure a proper diffusion of political initiative as between its thinly populated counties and those having concen-

${ }_{3} 273$ U.S. 536 (I927).

${ }^{85} 32 \mathrm{I}$ U.S. 649 (I944).

84286 U.S. 73 (1932).

${ }^{86} \times 65$ F. 2 d 387 (C.C.A. 4 th, 1947 ).

${ }_{87}$ Citing Myers v. Anderson, 238 U.S. 638 (I9I5). The I935 Amendment to the Illinois Election Code contains no severability clause.

${ }^{88}$ The Illinois Supreme Court has stated: "[T]he people registered their will that ... the vote of every qualified elector shall be equal in its infhuence with that of every other one, by Section I8 of the Bill of Rights, providing that all elections shall be free and equal" (italics added). Breckton v. Election Commissioners, 221 IIl. 9, 17,77 N.E. 321, 322 (I906).

${ }^{89} 328$ U.S. 549 (I946). Throughout the course of litigation counsel for the Progressive Party found it necessary to emphasize that Colegrove v. Green did not hold that equity has no jurisdiction to decide political questions. Only three of the seven justices who heard that case believed that equity did not have jurisdiction to decide it. Consequently the actual grounds of decision were those of Justice Rutledge, who specifically stated that equity did have jurisdiction, but thought that the Court should refuse to upset the existing apportionment in Illinois because the results of such action might prove disastrous.

${ }^{90} 335$ U.S. $28 x$ (1948).

9r Justice Rutledge's position is the same as that taken by him in Colegrove v. Green, 328 U.S. 549 ( 1946 ). See note 89 supra. His finding of want of equity, an exercise of the discretionary powers of a court of equity, was based upon his belief that any affirmative action taken by the Court was likely to lead to results more undesirable than those resulting from failure to act at all, and upon his belief that the decision of constitutional issues should be avoided whenever possible. See Colegrove v. Green, ibid, at 564 . 
trated masses.... The Constitution - a practical instrument of governmentmakes no such demand on the states."92

The issues in MacDougall $v$. Green were decided squarely upon the merits. Thus, the Court clearly took a step beyond the much discussed Colegrove v. Green where the decision rested upon want of equity. The language quoted gives reason to believe that a majority of the Court approves the notion that a state may, whether by failure to apportion legislative districts or by a requirement like that found in the Illinois Election Code, give increased political influence to particular segments of the population. Fortunately, the majority opinion in MacDougall v. Green provides a safeguard to prevent possible abuses of this power, such as the disenfranchisement of Negroes in the South by the substitution of a petition method of nomination for the primary, or by a gerrymandering of electoral districts: The "weighting" of votes or of voters' signatures must bear a reasonable relationship to a permissible end.

The Court stated that while it is true that the voters of the less populous counties have the power to completely block nominations, yet only thirty-nine per cent of the signatures need come from outside of Cook County. Cook County, which contains fifty-two per cent of the state's population, may provide up to sixty-one per cent of the signatures. Thus, the power which the Illinois statute grants to the less populous counties is not disproportionate to an allowable state policy, namely, "that candidates for state-wide office should have support not limited to a concentrated locality." The Court further pointed out that such a policy would assure a proper diffusion of political initiative, which is in turn justifiable in view of the fact that the residents of the populous counties have "practical opportunities for exerting their political weight at the polls" not available to the residents of the sparsely populated counties. ${ }^{93}$

Because of the inequitable apportionment of legislative districts, it would seem that in Illinois the "practical opportunities for exerting weight at the polls" might lie, in fact, with the residents of the less populous areas. Presumably what the Court was referring to are the organizational advantages available to party leaders in areas of concentrated population. The effect of the controverted amendment to the Election Code is to destroy these advantages insofar as they

92 MacDougall v. Green, 335 U.S. 28r, 282 (r948).

93 Ibid., at 2. In a state where almost half of the population lives in cities of 100,000 or more it is rather difficult to find any justification for a policy which prevents a political party from representing exclusively urban elements other than protection of the interests of already existent parties. The development of a minority party speaking solely for the urban population would in no way impair the ability of the non-urban populace to express itself politically. While the state legislature might conceivably have adopted the policy that all political parties should be cross-sectional, the legislative history of the Illinois statute in question shows no such conscious intent. The controverted provision requiring geographical distribution of signatures was added to a house bill by the Senate and passed both houses almost unanimously and with apparently very little debate. Ill. H. Jour. 575, 1764 (I935); Ill. S. Jour. 1073, 1396 (I935). No committee reports were published and no discussion of the measure appears in any Chicago newspapers of the period. 
effect the organization of new parties, and such is held to be permissible state policy.

On well-established constitutional grounds, the Supreme Court will be reluctant to strike down state laws regulating political matters. But in the instant case the majority went beyond a mere refusal to declare a law unconstitutional and actually gave explicit approval to the policy represented by the Ilinois election statute. The Court assumed that the geographical distribution requirement for petition signatures is a reasonable means to a permissible end-namely, the diffusion of political initiative. But it is these presumptions which raise the provocative questions in MacDougall v. Green.

Whether or not diffusion of political initiative was in fact the objective sought by the Illinois legislature when it passed the 1935 Amendment to the Election. Code, the proposition that such diffusion is desirable in itself, a thesis apparently accepted without question by the Court, is at least a debatable one. No one would deny that an increase in political initiative is desirable, and indeed essential, to a democracy. On the other hand, it is much less certain that a diffusion is likely to lead to an increase in political initiative-when diffusion goes too far it may become mere waste effort. In any event, the result of statutes such as the one in question will be to insure that any political party has widespread support, while at the same time insuring that there will be few political parties. It might well be argued that a maximum diffusion of political initiative, if that is desired, would be obtained under precisely converse conditions. ${ }^{94}$

In upholding the Illinois statute the Court said, "To assume that political power is a function exclusively of numbers is to disregard the practicalities of government." 95 This proposition was supported by reference to the United States Senate, which is based upon unequal representation of population. Yet, as Hamilton made clear in Number 62 of The Federalist ${ }^{16}$ the true basis of the sys-

94 After the decision of the Illinois Electoral Board on August $3 \mathrm{I}$ the Illinois law attracted wide attention in the press. Most of the comment, from all shades of political opinion, took the view that whatever its constitutionality, the statute was undemocratic and undesirable. See St. Louis Post-Dispatch, p. 4A, col. 3 (Oct. 23, I948); Chicago Daily News, p. I6, col. I (Oct. 26, I948); Chicago Sun-Times, p. 39, col. 4 (Oct. 21, I948), and p. 5, col. I (Sept. 2, r948); 36 New Statesman and Nation 209 (Sept. II, I948).

A contrary view is presented in the Yale Law Journal, op. cit. supra note $I$, at I 289, where it is said: "The requirement that such signatures be divided over a given number of counties is but a call to develop the extensive local organization without which a party cannot hope to win an election." But this view assumes that the placing of minor parties on the ballot is justified only if the party has some prospect of winning the election. The generally accepted view of the significance of minor party movements is in opposition to this premise. Authorities cited note rog infra. Furthermore, one of the main arguments relied upon by the Progressive Party in its attempt to invalidate the Illinois law was that a party might have the support of an absolute majority of the voters of the state and still not be able to nominate its candidates if those voters were concentrated in only a few counties, as they might conceivably be in a state like Ilinois where over half the population resides in a single county.

${ }_{95}$ MacDougall v. Green, 335 U.S. 28I, 282 (I948). The term 'political power' as used by the Court clearly refers to the ultimate basis of all political power-that power residing in the people by virtue of the franchise.

${ }_{96}^{6}$ The Federalist Papers 340 (Scott ed., 1902). 
tem of representation in the Senate is the fact that each constituent state remains a sovereign body. Story, in speaking of the Senate, went into this question at length. He wrote:

In the first place, the very structure of the general government contemplated one partly federal and partly national. It not only recognized the existence of the state governments; but perpetuated them, leaving them in enjoyment of a large portion of the rights of sovereignty.... [I]t would follow that a compound republic . . . ought to be founded on a mixture of proportional, and of equal representation.... If the house is to be proportional ... the senate should be fixed upon an absolute equality, as the representative of state sopereignty. 97

Since the Senate and the analogous Electoral College are the only examples of disproportionate representation recognized in the Constitution, it would seem that the Court, more accurately, might have said: Political power is a function of numbers exclusively, except insofar as modified by the demands of our federal system with its accompanying measure of state sovereignty.

In the instant matter, Illinois has given a disproportionate influence to the less populous counties. But counties are not sovereign bodies..$^{8}$ They have only such powers as may, for the time being, be delegated to them by the sovereign,"9 and, indeed, an attempt to delegate exclusively sovereign powers may be held invalid. ${ }^{100}$ Consequently it is submitted that the Supreme Court has pronounced a new constitutional principle-namely, that political power is not a function of numbers exclusively. As applied to the formation of new political parties, this principle permits a state to exclude such parties by means which are at once more effective and more subtle than the mere raising of total-signature requirements or other direct methods. As applied to a situation such as arose in Colegrove v. Green, the Court has now presumably decided that question upon the merits. Disproportionate voting influence, due to an inequitable apportionment of congressional or legislative districts, is not a violation of the Fourteenth Amendment. Further situations where this new principle will be applicable may well arise in the future. At the very least, the decision in MacDougall v. Green will serve as an open invitation to other states to adopt statutory provisions similar to those in Illinois in order to exclude minority parties from the ballot. ${ }^{10 r}$ Justices Douglas, Black, and Murphy, dissenting in MacDougall v. Green, thought that the I935 Amendment violated the equal protection clause of the Fourteenth Amendment. Nomination by petition, like nomination by primary,

97 I Story, Commentaries on the Constitution 492 (2d ed., I85I). Italics added.

${ }^{8}$ Calhoun County Court v. Mathews, 99 W. Va. 483, I29 S.E. 399 (I925); Keefe v. Schmiege, 25 I Wis. 79, 28 N.W. 2 d 345 (I947).

99 Laramie County v. Albany County, 92 U.S. 307 (1875); Thompson v. Lee County, 3 Wall. (U.S.) 327 (r865); Milliken v. Edgar County, $\mathrm{x}_{42}$ Il. 528, 32 N.E. 493 (I892).

200 Keefe v. Schmiege, 25I Wis. 79, 28 N.W. 2d 345 (1947).

${ }^{\text {xox }}$ Three other states now have geographical distribution requirements for nominating petition signatures. Ohio Code Ann. (Throckmorton, Supp., I948) §4785-9x; Mass. Ann. Laws (1947) c. 53, \&6; N.Y. Election Law (McKinney, 1947) § 137 (4). 
they said, is an integral part of the electoral process and is constitutionally protected. They concluded that a state law is invalid if discrimination results from its operation. ${ }^{\text {102 }}$

While the actual decision of the majority in MacDougall v. Green was neither unexpected nor unwarranted, the grounds upon which that decision was based came as a surprise from a court which has, in the long series of "white primary" cases, shown the greatest solicitude for the sanctity of the electoral process as a whole, and has been quick to impose the sanctions of the Fourteenth Amendment upon any state law which tended to discriminate against any group in its operation. ${ }^{\text {I03 }}$

\section{III}

The array of unforeseen complications and procedural problems which made their appearance during the course of the Progressive Party litigation in Illinois lends support to the theory that there should be a presumption against restrictions upon the free entry of minority parties to the political arena. But the exclusion of minority parties from the ballot might, of course, be justified on grounds of fundamental policy-as, for example, upon the premise that the preservation of the two-party system of government is contingent upon it. That a two-party, in contrast to a multi-party, system is characteristic of the most highly developed forms of political democracy and is, perhaps, the only framework within which democracy can effectively work, are propositions which have wide acceptance. ${ }^{\text {104 }}$

Admitting the superiority of a two-party system, it is nevertheless believed that rigid restrictions on the formation of new parties are not justified. ${ }^{\text {ros }}$ Quite

${ }^{02}$ MacDougall v. Green, 335 U.S. 28I, 285 (x948).

${ }^{{ }^{103}}$ See The Right To Vote in Southern Primaries, $x_{5}$ Univ. Chi. L. Rev. 756 (1948).

${ }^{104}$ Sait, op. cit. supra note 3, at 245; I Lowell, The Government of England 458 (3d ed., I9r2). The persuasive argument for this conclusion has been succinctly stated by Prof. Laski: "But the superiority of a two-party system over a multiplicity of groups is above all in this, that it is the only method by which the people can at the electoral period directly choose its government. It enables that government to drive its policy to the statute-book. It makes known and intelligible the results of its failure. . . The group-system always means . . . that the executive will represent, not a general body of opinion, but a patchwork of doctrines which compromise their integrity for the sake of power. It means, also, short-lived administrations, since reshuffling of the groups to overthrow the government is the most interesting exercise in which the legislature can indulge. ... While the group-system probably reflects more accurately the way in which the popular mind is actually divided, it is fatal to government as a practical art." Laski, A Grammar of Politics 3 I4 $_{4}$ (I929).

For contrary views see 2 Ostrogorski, Democracy and the Organization of Political Parties 652 (Ist ed., I902); Holcombe, Theory of Political Parties, 6 Encyc. Soc. Sci. 590 (1937).

${ }^{105}$ Ironically, the Comment in the Yale Law Journal, op. cit. supra note I, after examining and assessing the statutory provisions of all states, fails to include Illinois among the twenty states in which it is "difficult" for a third party to get on the ballot. It is believed, however, that the Ilinois law does present a serious obstacle to the appearance of minority parties on the ballot, although not for the reasons suggested by William H. Miller, State Director, Progressive Party, in a letter to the Yale Law Journal. Yale L.J., op. cit. supra note $\mathrm{x}$, at I $280 \mathrm{n}$. I6. The real obstacle lies in the admitted fact that the law prevents a party from representing 
apart from the civil liberties aspects of such restrictions ${ }^{106}$ there is little reason to believe that new minority parties pose a threat to the continuation of our twoparty system. At least two hundred years of Anglo-American political history bear ample witness to the unvarying ability of our political system to return always to its two-party form in spite of complete freedom of entry granted to new parties. ${ }^{107}$ Of course a new party has occasionally replaced one of the two established parties, ${ }^{\text {ro8 }}$ but it would be difficult to find any theoretical objection to this result.

The role of minor parties, however, is not primarily to compete with the major parties for the emoluments of political power, and it would be a serious mis-

exclusively urban elements. See note 93 supra. Another obstacle arises because the statute greatly eases the task facing objectors to the petitions by making it necessary for them successfully to challenge only a relatively small number of strategically located signatures. Without the distribution requirement the objectors must indiscriminately attack a long list which may contain two or three times the minimum required number of names unless the statute sets a maximum number of signatures.

Mr. Miller, in his communication to the Yale Law Journal, expressed his belief that since the average downstate county had a population of only ro,000 this would leave a reservoir of only about 2,500 eligible persons from whom to obtain the needed 200 signatures. As a matter of fact, only 9 of the I02 Illinois counties have a population of 10,000 or less, although $5 \mathrm{I}$ do have populations under 25,000. Mr. Miller also underestimates the ratio of registered voters to total population and overestimates the percentage of registered voters who vote at the primary. In any event, a new party will ordinarily concentrate its signatureseeking efforts in the more populous counties and will tend to ignore the smaller rural areas. An analysis of the 2I counties which were disputed before the Illinois Electoral Board shows that their total populations ranged from II,000 (Kendall) to II 3,000 (Rock Island). The total number of potential petition signers (i.e., total registered voters less those who voted at the primary) ranged from 4,500 to 55,000 , the mean average number being $I 7,972$ persons and the median number (Morgan County) being 12,705. This means that the Progressives, in order to get their two hundred signatures, would have had to obtain I.I I per cent of all potentially available signatures based on the mean average, or 1.57 per cent based on the median. These requirements are certainly not excessive and indicate that the real difficulty lies in the absence of any substantial urban population in most counties and in the severe practical difficulties faced by petition circulators in obtaining signatures and addresses that comply with the letter of the law as to form and detail. Population figures cited herein are from I6th Census of the United States ( 1940 ), General Characteristics of the Population, Vol. II, part 2, at 500. Primary vote figures are taken from Official Vote of the State of Illinois Cast at Primary Election, April I3, I948 (Office of Secretary of State, Springfield). Registration figures estimated from various sources.

In this connection it should be noted that the three minority parties which did appear on the November 1948 ballot in Illinois owe their appearance, in all probability, to the fact that their nominating petitions went unchallenged. This indicates that the mere presence or absence of minority parties on the state's ballot is not a good criterion for judging the severity of statutory restrictions.

${ }^{106}$ See American Civil Liberties Union, Minority Parties on the Ballot 2-8 (I940). The presence of statutory provisions for write-in votes does not in any substantial way serve as a substitute for minority parties as a means of giving expression to dissident political opinion. See Ragan v. Junkin, 85 Neb. I, 6, x22 N.W. 473, 475 (1909).

${ }^{107} \mathrm{~A}$ brief summary of these developments is presented in Sait, op. cit. supra note 3 , at $23^{\circ}$.

${ }^{208}$ The outstanding examples of this process are the growth of the British Labor Party and its subsequent replacement of the Liberal Party, and the rise of the Republican Party in the United States. 
take to judge their success solely in terms of the vote they receive. Traditionally, the role of third parties has been to serve as generators of new ideas which are then adopted and effectuated by one of the major parties. Political scientists have almost universally recognized this role as an extremely valuable one. ${ }^{\text {xog }}$ It would seem especially valuable in a nation where, until recently at least, both major parties have been cross-sectional parties with platforms that have tended to duplicate each other to a large extent..150

Efforts to exclude third parties from the ballot have also been justified on the ground that the public has an interest in keeping the ballot unencumbered. Yet the type of encumbrance which results from the addition of two or three additional party columns to the ballot is not of the same nature as that which results from the proverbial "six-foot ballot," where the average voter has never heard of the offices being contested, let alone the candidates running for them. Certainly, the public interest in the free circulation of new ideas should be controlling. ${ }^{\text {.rr }}$

Since the influence of dissident opinion only rarely becomes effective through the minor party itself, but usually achieves effectiveness only through the force it exerts on major-party policy, it has sometimes been suggested that the minor party is really extraneous-that a new or unpopular idea actually becomes acceptable through mechanisms which lie outside the political party itself, and that consequently the minor party serves no important function. ${ }^{\text {rxz }}$ But several reasons are apparent why political parties are likely to prove more effective than nonpolitical movements as channels for the introduction of new ideas. The threat of direct competition for votes is an extremely effective means of forcing ideological concessions from the major parties or of actually assuming control of a major party. ${ }^{113}$ Furthermore, a psychological factor is involved: Followers of a

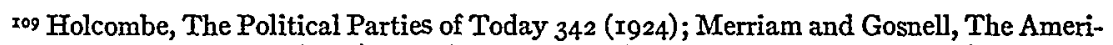
can Party System 34, 37 (1940); Herring, The Politics of Democracy I8I (1940); Haynes, Third Party Movements since the Civil War 2 (I9I6); Binkley, American Political Parties I8I (1943).

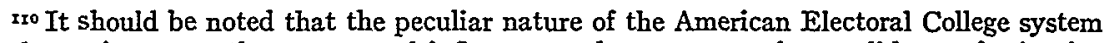
tends to give a greatly exaggerated influence to the votes cast for candidates of minority parties, a situation well illustrated by the recent election in connection with Mr. Wallace's votes. Although this fact has sometimes been used as an argument against minority political parties, it would seem more properly to be an argument for the abolition or reform of the Electoral College, an institution which apparently presents no compensating features.

trx A brief description of the "short ballot" movement will be found in Merriam and Gosnell, The American Party System 285-86 (I940). In Great Britain cluttering-up of the ballot is avoided by a requirement that all candidates for parliament deposit a sum of $£_{15}$. If the candidate fails to receive one-eighth of the total vote cast in the district the deposit is forfeited. This has proved quite effective in keeping the "nuisance" candidate off the ballot while at the same time presenting no great obstacle to the candidates of minority groups. Representation of the People Act, 7 \& 8 George V, c. 64, $\$$ 26, 27 (x918); I2 Halsbury's Laws of England 252, 320 (2d ed., x948).

r2 Sait, op. cit. supra note 3, at 302 .

${ }^{213}$ It is doubtful whether the National Non-Partisan League would have been able to capture control of the North Dakota Republican organization in the years just prior to I920 if the League had not been a tightly organized political group. See Wilcox, An Historical Definition of Northwestern Radicalism, 26 Miss. Valley Hist. Rev. 377 (I939). 
new doctrine like to believe, however remote the possibility of realization, that their candidates will shortly sweep into the seats of political power, and the promise of such an event is an effective means of gaining support. And finally, of course, there is always the possibility of the minor party actually replacing one of the major parties, a possibility which, though remote, should not be ignored.

\section{THE GROWTH OF THE INTERNATIONAL SHOE DOCTRINE}

When residents of one state carry on business in another state through their agents, the courts of the latter state cannot acquire jurisdiction in personam over the nonresidents under the historical prerequisite of the presence of the

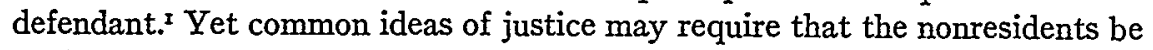
subject to suit in the courts of the state in which they are doing business. Until recently, the principal's absence from the state was thought to deny its courts any power over him, if he were an individual. When the principal was a juristic person further complexities appeared, ${ }^{2}$ but the courts found it easier to develop jurisdictional doctrines to meet the situation. Thus, under some circumstances, the foreign corporation may be denied the privilege of doing business in the state unless it has designated an agent in the state upon whom service of process may be made. In the absence of such express consent by the corporation to the exercise of jurisdiction, ${ }^{3}$ proper service of process ${ }^{4}$ may nevertheless give a court jurisdiction to render a personal judgment against the corporation. This power has been based upon various concepts, the courts most often referring to the "implied consent" of the corporation to the exercise of jurisdiction, ${ }^{5}$ or to the "presence" of the corporation wherever its activities are being carried on. ${ }^{6}$ The

$x$ Unless, of course, the nonresident, if an individual, happens into the state at an opportune moment.

${ }^{2}$ Early in the nineteenth century it was thought impossible to acquire jurisdiction in personam over a foreign corporation. Middlebrooks v. Springfield Fire Ins. Co., I4 Conn. $3^{\circ I}$ (184I); Henderson, The Position of Foreign Corporations in American Constitutional Law 77 et seq. (I9I8).

3 When the corporation has expressly consented to jurisdiction over it, the extent of the authority thereby conferred is a question of interpretation of the instrument of consent or of the statute requiring it. Thus, the authorization of the agent to accept service of process may include causes of action arising in other states. Pennsylvania Fire Insurance Co. v. Gold Issue Mining and Milling Co., 243 U.S. 93 (I9I7); Smolik v. Philadelphia \& Reading Coal and Iron Co., 222 Fed. 148 (D.C. N.Y., rgr 5). Or it may be construed to refer only to causes of action arising out of business done in the state. Dunn v. Cedar Rapids Engineering Co., I52 F. 2d 733 (C.C.A. 9th, I945). Cases involving express consent are not considered in this note.

4 Of course, a judgment against a foreign corporation, or any other defendant, is void unless the method of service employed is reasonably calculated to give notice to the defendant and to afford it an opportunity to be heard. Rest., Judgments $\$ \S 6,3 \circ$ (I942); I Beale, Conflict of Laws $\$ 89.3$ (I935). This note is concerned with the other element of jurisdiction-the power of a state to subject a person to its control.

$s$ Lafayette Insurance Co. v. French, r8 How. (U.S.) 404 (1855); Mutual Life Insurance Co. v. Spratley, 172 U.S. 602 ( 1899 ).

${ }^{6}$ International Harvester Co. v. Kentucky, 234 U.S. 579 (19I4); Philadelphia \& Reading Ry. Co. v. McKibbin, 243 U.S. 264 (I9r7); Bank of America v. Whitney Cent. Nat. Bank, 261 U.S. I7I (I923). 